\title{
Correction: BET 2: Blood biomarkers as an alternative to imaging in diagnosing acute ischaemic stroke
}

Jane J, Lo R, Graham. CA BET 2: Blood biomarkers as an alternative to imaging in diagnosing acute ischaemic stroke. Emerg Med J 2018;35:336-338. doi: 10.1136/emermed-2018-207686.2

The full and correct name of the first author of this article is: Jessica Jane SY.

(c) Article author(s) (or their employer(s) unless otherwise stated in the text of the article) 2018. All rights reserved. No commercial use is permitted unless otherwise expressly granted.

Emerg Med J 2018;35:522. doi:10.1136/emermed-2018-207686.2corr1

D) Check for updates 